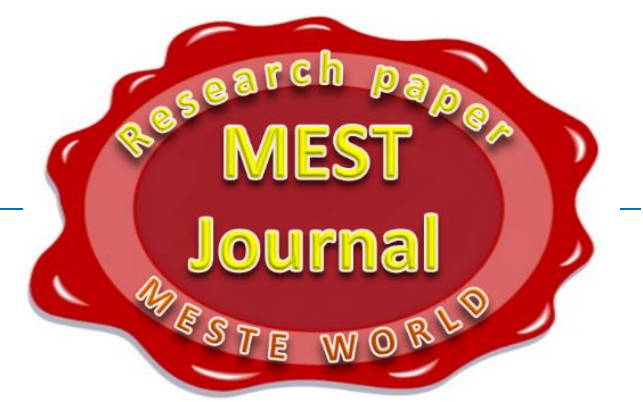

\title{
INDICES OF ENVIRONMENTAL PERFORMANCE OF THE COMPANIES FROM THE AUTOMOBILE SECTOR IN THE CONTEXT OF INTEGRATED REPORTING
}

\author{
Desislava Yosifova \\ Todor Kableshkov University of Transport, Sofia, Bulgaria \\ Magdalena Petrova-Kirova \\ Todor Kableshkov University of Transport, Sofia, Bulgaria
}

OMESTE

JEL Category: L62, Q01

\begin{abstract}
Until very recently business operations were most strongly motivated by the ambition to maximize financial return and the purpose of the corporate accounting statements was to present information mainly on the cash flow, the financial and the asset position, as well as the financial outcome of the company. Development of world economy and the thereby arising positive and negative effects on society are not fully covered by conventional accounting and financial reporting system. The insufficiency of such information obstructs satisfying the information needs of various interested parties, resulting in growing expectations and pressure over the companies to accept not only the positive, but also the negative effect on their behaviour in economic, environmental and social aspect. All of the above prerequisites, along with the capital restriction the companies are facing, require a change towards an appropriate upgrade of traditional corporate reporting. This problem is particularly significant for Bulgaria, which, being a member state of the EU, is expected to apply all European Directives for implementation of environmental requirements essentially related to transport sector. In addition, the country's geostrategic position, through which territory 5 of the ten Pan-European transport corridors run through, makes the problems related to the development and the application of methodologies and the toolkit for covering, registration and reporting of the effect of transport companies' activities (especially those in the automobile sector) on environment, people and society as a whole, particularly important. Integrated reporting is ready to face these challenges and to solve a significant part of the problematic fields, which, in complex with the data and the indicators, registered and accounted for by traditional financial reporting, can provide together, to a sufficient and full extent, the demand for information in the implementation of environmental policy on national, local and global scale.
\end{abstract}

The address of the corresponding author: Desislava Yosifova 莑"diosifova@abv.bg
Keywords: automobile transport, integrated reporting, sustainable development, capital types, key indicators 


\section{INTRODUCTION}

In terms of geostrategy, Bulgaria's geographic position is a prerequisite for the country to become a transport bridge between the West and Central European countries and those from the Near East, West and Central Asia, not to mention the convenient access from the country's territory to the Black Sea region. Bulgarian transport network is called upon to collaborate in improving the functioning of the European single market by providing efficient transport links through Bulgaria, ensuring the movement of people and goods and the access to other countries and markets. Bulgaria's accession to the EU established the relevant geoeconomic opportunities for the use and the development of the cross-border transport corridors TC№4, TC№7, TC№8, TC№9 n TC№10. The total length of Pan-European transport corridors on the territory of Bulgaria only by land is $1960 \mathrm{~km}$ (and $470 \mathrm{~km}$ more on the river Danube).

Furthermore, the picture illustrating the age structure of the automobiles in Bulgaria is far from optimistic. The major part is represented by automobiles of above 20 years of age, whereas $69 \%$ of all light vehicles are above 15 years of age. The share of the new light vehicles is the smallest, those under 5 years are under $3 \%$, and the ones between 6 and 10 years $-7 \%$. Bulgaria's largely depreciated vehicle fleet, as well as the continuing trend of growing import of 'second hand' cars, requires that Bulgaria strictly complies with European environment related legislation and implements an adequate national policy in the field of control, recycling and utilization of the 'end-of life" vehicles. Due to the data, reported by the relevant structure - Executive Environment Agency (2018), the average annual volume of the recycled vehicles for the past 2-3 years is approximately $2.5 \%$.

In view of meeting the provisions laid down in the European Directives and the specific environmental requirements of Bulgarian legislation (2016), it was concluded that along with the accounting information, the integrated reporting is one of the significant instruments to implement environmental policy and subsequently follow and control the responsibility of the relevant segments along the chain for value creation in all waste producing sectors. Automobile sector is without a doubt one of the most harmful sectors for the environment, but also has the highest potential for management and treatment of the harms and waste caused by it, to the benefit of global nature and economy.

European Directives define quantitative targets for a few types of widespread waste:

- end-of life vehicles;

- out-of-use electrical and electronic equipment;

- $\quad$ spent batteries and accumulators;

- packaging waste.

Bulgaria has established quantitative targets for collection, reuse, recycling, and utilization of 6 types of widespread waste, where apart from the above mentioned 4 , there are individual legal acts in regard with waste tyre and waste oils ${ }^{1}$. Accordingly, of all 6 types of widespread waste, 5 are in one way or another, related to vehicle manufacture and use.
${ }^{1}$ There is a specific regime regulation regarding the waste oils (WO) at EU level. The act that used to regulate this type of waste initially, was Directive 75/439/EEC on the disposal of waste oils (WO Directive). The Directive was cancelled in 2010 and currently the waste oils matter is fully transferred to and covered by the framework Directive 2008/98/EC on waste. This Directive establishes requirements for the Member States to undertake relevant measures to guarantee that: - waste oils are collected separately, where this is technically feasible. waste oils are treated with priority to regeneration or as an alternative to other recycling activities.

- waste oils of different characteristics are not mixed, and waste oils are not mixed with other kinds of waste or substances if such mixing impedes their treatment. There has been regulated the application of measures, such as: technical requirements, manufacturer/ importer's responsibility, economic instruments, or voluntary agreements. 
To take responsibility for their behaviour and operation and the thus arising positive and negative economic, social, and environmental effects, significant to the interested parties and the society as a whole, the transport sector companies should prepare integrated statement.

The need for integrated reporting is intensified by the fact that during the last decade, in Bulgaria, we observe a serious growth in the volume of the freight (and passenger as well) road transportation on one hand, and on the other hand - the related environmental pollution, as well as increase in the number of road accidents. Approximately $65 \%$ of the share of the transported goods in Bulgaria is taken by the road freight transport (RFT).

Table 1. Transported Goods - Automobile Transport thousand tons for the period 2010 2016

\begin{tabular}{|l|c|c|c|c|}
\hline \multicolumn{1}{|c|}{ Years } & 2011 & 2013 & 2015 & 2016 \\
\hline $\begin{array}{l}\text { RFT against } \\
\text { payment }\end{array}$ & 58,884 & 79,398 & 85,234 & 82,543 \\
\hline $\begin{array}{l}\text { RFT against } \\
\text { payment and } \\
\text { for its own } \\
\text { account total }\end{array}$ & 135,276 & 160,267 & 161,806 & 147,136 \\
\hline
\end{tabular}

Source: prepared authors based on data from the National Statistical Institute (NSI, 2016)

The purpose of this research is to present opportunities to expand and improve the nonfinancial reporting while paying particular attention to the business model of the company. Based on the analysis ${ }^{2}$ carried out, there have been deduced some key indicators for environmental performance, which, along with the developed matrix of interaction between the different types of capital and the business model, are to be included as a part of the integrated reporting of the transport companies, whereas the model is particularly appropriate for the automobile sector being one of the biggest sources of environmental pollution. Thus, the given companies would perform the modern expectations and requirements for implementation of the environmental policies in Europe and globally much more reliably .

${ }^{2}$ Due to the limitations in the volume of the research, the analysis is not part of this report.

\section{BUSINESS MODEL AS A KEY FACTOR IN THE STRUCTURING AND THE ESTABLISHMENT OF INTEGRATED REPORTING}

According to the International Integrated Reporting Framework (IIRF), the success of each company greatly depends on the various resources used by the company and the links between them. These resources can be considered within the context of the various types of capital: financial, productive, human, intellectual, social and environmental. The various companies (from the various sectors of economy) have various types of capital, as not all capitals are applicable to all companies. The interaction between the types of capital for the different companies is different. This has to do with the extent, to which the various companies benefit from and influence each and every type of capital. As of accounting and economic point of view, this interaction is the so called circulation of capital, as a result of which, the company implements its activity and achieves certain results and accordingly creates value for the relevant parties.

Crucial significance for the process of value creation has the business model of the company.

Economy related literature contains numerous definitions about the essence of the business model. Most often, it is considered "a process through which the organization aims to create and maintain value."(Yonkova, 2012) The creation of value in short-term, medium-term and long-term period is achieved via organization and management of the various types of capital, the business operation, the products, accordingly the services, and the performance and its directing towards achieving the strategic goals of the company. On the other hand, ''model' in the economic sense of the term is being considered a theoretical construction presenting economic processes via a set of variables, as well as a set of logical and/or quantitative relations between them. The economic model is a simplified framework meant to illustrate complex processes". (Kolev, Raynov, 2017) 
The business model concept is presented in the Conceptual Financial Reporting Framework, i.e., there has been included a requirement for the companies, reporting in accordance with IAS/IFRS, to include a business model of their company in their financial statements.

Table 2 Interaction Between the Types of Capital in the Value Creation Process

\begin{tabular}{|c|c|c|c|c|c|c|}
\hline \begin{tabular}{|c|} 
Direction \\
of the \\
impact
\end{tabular} & Financial & Productive & Human & Intellectual & Social & Natural \\
\hline 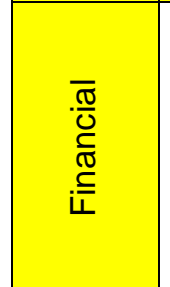 & $X$ & $\begin{array}{c}\text { Increase in } \\
\text { the volume } \\
\text { and the } \\
\text { quality of the } \\
\text { manufactured } \\
\text { products }\end{array}$ & $\begin{array}{c}\text { Growth in } \\
\text { financial } \\
\text { results, } \\
\text { productivity, } \\
\text { and labor } \\
\text { quality }\end{array}$ & $\begin{array}{l}\text { Growth in the } \\
\text { manufacturing } \\
\text { of competitive } \\
\text { products, } \\
\text { decrease of } \\
\text { financial risk }\end{array}$ & $\begin{array}{c}\text { Usage of } \\
\text { union } \\
\text { organiza- } \\
\text { tions' } \\
\text { opportunities }\end{array}$ & $\begin{array}{l}\text { Manufactu- } \\
\text { ring of } \\
\text { ecological } \\
\text { production }\end{array}$ \\
\hline $\begin{array}{l}\stackrel{0}{\geq} \\
\frac{0}{0} \\
\frac{0}{0} \\
\frac{0}{0}\end{array}$ & $\begin{array}{l}\text { Production facilities } \\
\text { modernisation }\end{array}$ & $x$ & $\begin{array}{c}\text { Introduction } \\
\text { of } \\
\text { innovations } \\
\text { in business } \\
\text { processes }\end{array}$ & $\begin{array}{c}\text { Introduction of } \\
\text { technological } \\
\text { equipment in } \\
\text { the construction } \\
\text { of facilities }\end{array}$ & $\begin{array}{c}\text { Implementati } \\
\text { on of } \\
\text { beneficial } \\
\text { capital } \\
\text { investments } \\
\text { for society }\end{array}$ & $\begin{array}{c}\text { Energy } \\
\text { saving as a } \\
\text { manner of } \\
\text { environ- } \\
\text { mental } \\
\text { protection }\end{array}$ \\
\hline 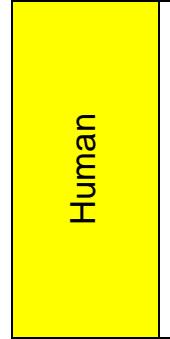 & $\begin{array}{l}\text { Engaging and } \\
\text { training qualified } \\
\text { specialists }\end{array}$ & $\begin{array}{l}\text { Creation of } \\
\text { improved } \\
\text { working } \\
\text { conditions }\end{array}$ & $x$ & $\begin{array}{c}\text { Expansion of } \\
\text { the } \\
\text { opportunities for } \\
\text { development of } \\
\text { all types of } \\
\text { competencies } / \mathrm{s} \\
\text { kills }\end{array}$ & \begin{tabular}{|l|} 
Trust, \\
readiness to \\
cooperate
\end{tabular} & $\begin{array}{l}\text { Health } \\
\text { protection } \\
\text { of staff's } \\
\text { creativity }\end{array}$ \\
\hline 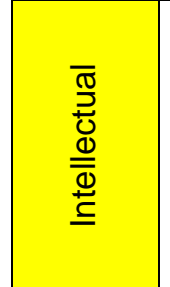 & $\begin{array}{l}\text { Intellectual property } \\
\text { acquisition }\end{array}$ & $\begin{array}{c}\text { Opportunity } \\
\text { for creation of } \\
\text { intellectual } \\
\text { property }\end{array}$ & \begin{tabular}{|c|} 
Creation of \\
intellectual \\
property - \\
"organizati- \\
onal capital"
\end{tabular} & $x$ & $\begin{array}{l}\text { Discussion } \\
\text { of common } \\
\text { regulations } \\
\text { in corporate } \\
\text { precedures }\end{array}$ & $\begin{array}{l}\text { Maintaining } \\
\text { ecosys- } \\
\text { tems' well- } \\
\text { being by } \\
\text { intellectual } \\
\text { property }\end{array}$ \\
\hline $\begin{array}{l}\bar{\pi} \\
\frac{\pi}{0} \\
\infty\end{array}$ & $\begin{array}{l}\text { Implementation of } \\
\text { social } \\
\text { investments, deve- } \\
\text { lopment of long- } \\
\text { term relations }\end{array}$ & $\begin{array}{c}\text { Opportunity to } \\
\text { participate in } \\
\text { union } \\
\text { organisations }\end{array}$ & \begin{tabular}{|c|} 
Exchange of \\
experience \\
for welfare \\
develop- \\
ment
\end{tabular} & $\begin{array}{l}\text { Opportunity to } \\
\text { participate in } \\
\text { strategic } \\
\text { alliance }\end{array}$ & $x$ & $\begin{array}{l}\text { Environ- } \\
\text { mental } \\
\text { protection } \\
\text { institutions }\end{array}$ \\
\hline 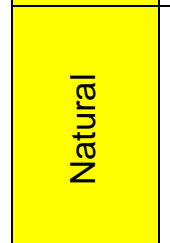 & $\begin{array}{l}\text { Implementation of } \\
\text { investments in } \\
\text { relation to } \\
\text { environmental } \\
\text { protection }\end{array}$ & $\begin{array}{c}\text { Reduction of } \\
\text { negative } \\
\text { environmental } \\
\text { effects }\end{array}$ & $\begin{array}{c}\text { Care for } \\
\text { environment } \\
\text { al wellbeing }\end{array}$ & \begin{tabular}{|} 
Development of \\
ecological \\
manufacturing \\
processes and \\
products
\end{tabular} & $\begin{array}{l}\text { Environmen- } \\
\text { tal initiatives' } \\
\text { legislative } \\
\text { consolida- } \\
\quad \text { tion }\end{array}$ & $x$ \\
\hline
\end{tabular}

Source: prepared by authors

In the context of the International Integrated Reporting Framework (IIRF), the business model of the company is regarded as a system for conversion/transformation of capitals through their (of the company) business activity, in products, accordingly - services, and performance directed towards achieving the strategic goals of the company and creation of value in short-term, medium-term and long-term period. 
The participance of the different types of capital in the company operation leads to their conversion/transformation from one form of capital to another. Using this constant circulation of the capital, the company creates value in time.

This capital circulation differs, depending on the scope of activity of the company and should be presented in more detail, including the interaction between the different types of capital as an element of the company business model and accordingly - as a part of the Annual Integrated Statement.

The interaction between the various types of capital (Malinovskaya, 2016) within the matrix is bidirectional: the vertical direction presents the influence of one type of capital over another and the respective arising transformation. Horizontally, the table demonstrates the result of this influence, respectively - transformation. Depending on the phases of the capital circulation, the interactions between the different types of capital can be classified into five relations:

- Financial - Productive Capital or the modification is in the form of the capital - from cash to material form. This transformation will not lead to a change in the asset value of the company but will cause structural modifications.

- The same applies to the relation Financial Intellectual Capital, which is practically investment in intangible assets of the company. The reversed relation - Productive - Financial Capital presents the effect/result of the investment, related to the raise in the sale profit. That, in turn, leads to modification in the equity.

- Financial - Human Capital: training, qualification and retraining of staff is of essential importance to a company. Investment in knowledge and skills, necessary to perform the company operational activity, is a part of the second phase of the capital circulation - manufacturing. The effect of this investment, presented along the horizontal of

${ }^{3}$ The Global Reporting Initiative is an international non-governmental organization based in Amsterdam, the Netherlands,founder of the sustainable development reporting. It was established in 1997 in Boston, and its mission is to the matrix, is related to an increase in labour productivity, which, in turn, reflects on company's profitability.

- Financial - Social Capital: transformation of financial into another type of capital with social impact suggests positive change regarding the company's social image. This, on the other hand, influences the market assessment of the company (in case it is listed on the Stock Exchange) or raises the index of market capitalisation.

- Investments related to natural capital: Financial - Natural capital can also be regarded in view of capital transformation from cash to material. Environmental protection related investments are of an essential significance for the achievement of sustainable development. Referred to transport sector as a major pollution maker, the acquisition of vehicles complying with the highest environmental standards - EURO 5 and EURO 6 - leads to a decrease in the exhaust emissions, released into the atmosphere. Capital transformation affects cash form which is being converted into material in the process of investment.

\section{SUSTAINABLE DEVELOPMENT REPORTING STANDARDS IN ACCORDANCE WITH THE GLOBAL REPORTING INITIATIVE}

By establishing standards for sustainable development reporting, the Global Reporting Initiative (GRI, 2018) provides secure and reliable reporting structure which can be used by small-, middle- and large-scale enterprises, regardless of the industrial sector they operate in. The standards say that "GRI's reporting structure is intended to serve as a reporting model for the economic, environmental and social performance" of the companies in all sectors. As by GRI data ${ }^{3}$ $93 \%$ of the largest 250 enterprises in the world report their sustainability. Many of the companies that have adopted integrated reporting as a form

create opportunities for solutions, via which the companies can create economic, social, and environmental benefits for all parties. 
of reporting, prepare their integrated reports mainly in compliance with the GRI standards (2018) and the indices of economic, social and environmental performance along with the International Integrated Reporting Framework (IIRF).

\subsection{Environmental Indices}

1) EN3 is a key environmental indicator, related to the direct energy consumption as by major energy resources

For the needs of the analysis, the costs for resources, fuels and lubricants for the vehicles of a transport company ${ }^{4}$, electricity and other type of energy are included as the major energy costs:

Table 3. Costs for Raw Materials, Fuels, Electricity and Other Types of Energy

\begin{tabular}{|c|c|}
\hline Year & $\begin{array}{c}\text { Costs for Raw Materials, Fuels, } \\
\text { Electricity and Other Types of } \\
\text { Energy } \\
\text { (thousand BGN) }\end{array}$ \\
\hline 2016 & 59421 \\
\hline 2015 & 66912 \\
\hline 2014 & 69840 \\
\hline 2013 & 61138 \\
\hline 2012 & 61138 \\
\hline 2011 & 41325 \\
\hline
\end{tabular}

Source: prepared by authors

2) The EN16 indicator reflects the total weight of the greenhouse gas emissions, emitted into the atmosphere (GRI, 2016).

The implementation of road freight transportation by emitting dust and exhaust emissions, as well as the arising noise pollution, affect biosphere in a negative way and cause damage to human health, climate changes and greenhouse effect.

${ }^{4}$ For the needs of the analysis, data from Annual Financial Statements has been used, as well as additional information about the transport company PIMK LTD, which is one of the largest enterprises in the international transport and freight forwarding sector in Bulgaria with more than 20 years of experience in the field of transportation of goods with deliveries all over Europe, parts of Asia and Africa.
Approximately $94 \%$ of the greenhouse gas emissions from transport are a result of automobile transport. $^{5}$ For 2014, automobile transport was the source of approximately $99 \%$ of the carbon dioxide, emitted by transport as a whole.

The total fuel consumption in Bulgaria for 2014 in automobile transport grew by $6.44 \%$ (as compared to 2007). ${ }^{6}$ (The Integrated Transport Strategy, 2017)

Fig. 1 clearly demonstrates the growing trend in road freight transportation in Bulgaria.
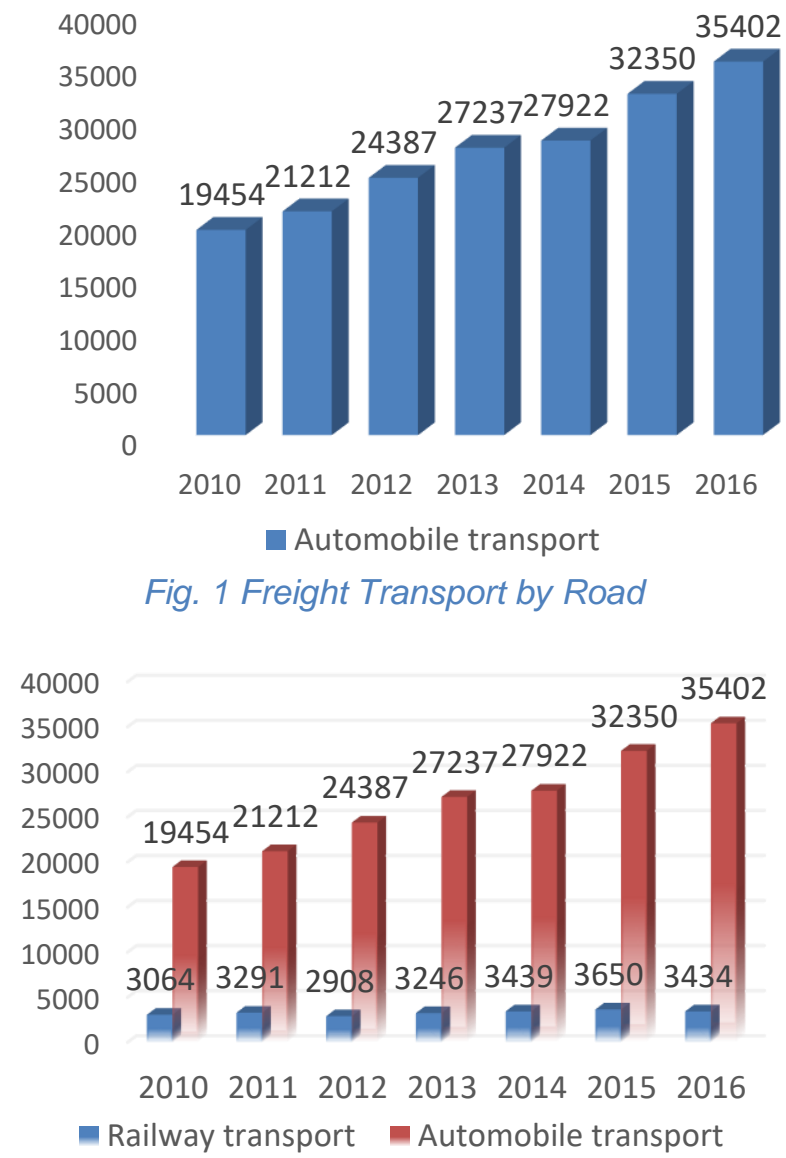

Fig. 2 Structure of Road and Railroad Freight Transport

${ }^{5}$ The main greenhouse gases, included in the United Nations Framework Convention on Climate Change (see Integrated Transport Strategy for the period until 2030) are as follows: carbon dioxide $\left(\mathrm{CO}_{2}\right)$, methane $\left(\mathrm{CH}_{4}\right)$, dinitrogen oxide $\left(\mathrm{N}_{2} \mathrm{O}\right)$, hydrofluorcarbons (HFCs), perfluorcarbons (PFCs), sulphur hexafluoride $\left(\mathrm{SF}_{6}\right)$ 
In Bulgaria the freight forwarding activity in automobile transport for 2016 increased with approximately $82 \%$ in comparison with 2010 2011. There was an increase by $12 \%$ for the same period in railway transport as well. Comparing the same data to 2015 , it is appropriate to summarize that the growing trend in freight forwarding activity in the automobile transport continues. The increase rate is approximately $9.5 \%$, compared to 2015. There was a decrease in railway transportation for 2016 in comparison with 2015 by approximately $6 \%$. (NSI, 2016) This fact obstructed the implementation of strategic goal No. 3 from the Integrated Transport Strategy (2017) for the period until 2030 - limitation of the negative impact from the development of transport sector. The priority for the achievement of this goal is limitation of the negative impact of transport on environment and people's health, which is related to achieving sustainable development in transport.

Table 4. Emissions of Pollutants in the Air by Automobile Transport in Bulgaria [in tons]

\begin{tabular}{|l|r|r|r|r|r|r|}
\hline & \multicolumn{7}{|c|}{ Year } \\
\hline Pollutants & $\mathbf{2 0 1 1}$ & $\mathbf{2 0 1 2}$ & $\mathbf{2 0 1 3}$ & $\mathbf{2 0 1 4}$ & $\mathbf{2 0 1 5}$ & $\mathbf{2 0 1 6}$ \\
\hline Sulphur Oxides (SOx) & 124 & 126 & 99 & 107 & 37 & 38 \\
\hline Nitrogen Oxides (Nox) & 40145 & 41645 & 36002 & 38833 & 45407 & 47196 \\
\hline $\begin{array}{l}\text { Non-Methane Volatile } \\
\text { Organic Compounds }\end{array}$ & 14884 & 14922 & 12889 & 12822 & 13468 & 11522 \\
\hline Methane $\left(\mathrm{CH}_{4}\right)$ & 1060 & 1061 & 980 & 1109 & 1118 & 1030 \\
\hline Carbon Oxide $(\mathrm{CO})$ & 82023 & 76448 & 65258 & 70642 & 72396 & 67860 \\
\hline Carbon Dioxide $(\mathrm{CO})$ & 7492640 & 7822170 & 6849525 & 7899542 & 8684244 & 8795963 \\
\hline Dinitrogen $\mathrm{Oxide}_{2}\left(\mathrm{~N}_{2} \mathrm{O}\right)$ & 211 & 222 & 201 & 231 & 259 & 268 \\
\hline Ammonia $\left(\mathrm{NH}_{3}\right)$ & 741 & 739 & 772 & 901 & 959 & 900 \\
\hline
\end{tabular}

Table 5. Relative Share of PIMK LTD's Carbon

Dioxide Emissions in the Air

\begin{tabular}{|c|c|c|c|}
\hline Year & $\begin{array}{c}\text { Absolute } \\
\text { values } \\
\text { (tons) }\end{array}$ & $\begin{array}{c}\text { Relative } \\
\text { values } \\
\text { (\%) }\end{array}$ & Coefficient \\
\hline 2016 & 337765 & $3.84 \%$ & $\mathbf{0 . 0 3 8 4}$ \\
\hline 2015 & 426396 & $4.91 \%$ & $\mathbf{0 . 0 4 9 1}$ \\
\hline 2014 & 344420 & $4.36 \%$ & $\mathbf{0 . 0 4 3 6}$ \\
\hline 2013 & 298639 & $4.36 \%$ & $\mathbf{0 . 0 4 3 6}$ \\
\hline 2012 & 283945 & $3.63 \%$ & $\mathbf{0 . 0 3 6 3}$ \\
\hline 2011 & 216537 & $2.89 \%$ & $\mathbf{0 . 0 2 8 9}$ \\
\hline
\end{tabular}

Source: as by data of PIMK Ltd.
PIMK LTD's automobile fleet complies with European environmental emission standards Euro 5,6 and EEV. The relative share of the exhausted emissions of the company is presented in table 5 .

3) The environmental indicator EN30 represents the total costs (investments) made by the companies in relation to environmental protection (GRI, 2016).

For the needs of the research, there has been used the value of the fixed assets, accordingly the amount of vehicles complying with the requirements of Euro 5 and Euro 6 environmental standards, in which the company is investing. 
Yosifova, D. Indices of environmental performance of companies

MEST Journal Vol. 9 No.1 pp. 207-215

Table 6. Fixed Tangible Assets (FTA) for Road Freight Transport Sector and for PIMK Ltd for the period 2011 - 2016, in BGN (in thousand BGN)

\begin{tabular}{|c|c|c|c|c|}
\hline Year & $\begin{array}{c}\text { FTA - sector } \\
\text { RFT }\end{array}$ & $\begin{array}{c}\text { FTA } \\
\text { PIMK Ltd. }\end{array}$ & $\begin{array}{l}\text { Vehicles } \\
\text { PIMK Ltd. }\end{array}$ & $\begin{array}{l}\text { Relative Share of } \\
\text { Vehicles in the } \\
\text { Structure of FTA }\end{array}$ \\
\hline 2016 & 5796224 & 148650 & 144224 & $97,02 \%$ \\
\hline 2015 & 5443788 & 155571 & 148067 & $95,18 \%$ \\
\hline 2014 & 4608400 & 113322 & 108655 & $95,88 \%$ \\
\hline 2013 & 4348302 & 115904 & 103324 & $89,15 \%$ \\
\hline 2012 & 3979398 & 82179 & 71540 & $87,05 \%$ \\
\hline 2011 & 3872330 & 61949 & 54304 & $87,66 \%$ \\
\hline
\end{tabular}

Source: prepared by authors

For the needs of the analysis, table 7 presents the data about the purchased vehicles in thousand BGN as by years for the period $2011-2016$ :

Table 7. Vehicles - PIMK LTD (thousand BGN) $2011-2016$

\begin{tabular}{|c|c|c|}
\hline Year & $\begin{array}{c}\text { Vehicles as } \\
\text { by Carrying } \\
\text { Amount } \\
\text { (thousand } \\
\text { BGN) }\end{array}$ & $\begin{array}{c}\text { Purchased } \\
\text { Vehicles as by } \\
\text { Book Value } \\
\text { (thousand BGN) }\end{array}$ \\
\hline 2016 & 144224 & $\mathbf{4 0 ~ 4 2 9}$ \\
\hline 2015 & 148067 & $\mathbf{8 8 5 1 8}$ \\
\hline 2014 & 108655 & $\mathbf{4 5 3 3 5}$ \\
\hline 2013 & 103324 & $\mathbf{6 4 0 0 0}$ \\
\hline 2012 & 71540 & $\mathbf{3 6} \mathbf{4 4 0}$ \\
\hline 2011 & 54304 & $\mathbf{4 0 4 1 8}$ \\
\hline
\end{tabular}

Source: prepared by the authors as by data from the Annual Financial Statement of PIMK LTD

\section{CONCLUSION}

By preparing a unified integrated statement, the company should upgrade from reporting format oriented mainly towards financial performance to a format demonstrating how the company business model participates in the transformation of the available capitals (producing, natural and human resources) and the creation of value for the major related parties.

The proposed model of matrix of interaction between the various types of capital adjusted for transport sector companies and particularly applicable to those from the automobile transport, along with the deduced key environmental indices, provides opportunities for periodic improvement of the business model and subsequent achievement of higher created value by these companies as an instrument for implementation of the environmental policies in Europe and globally, in medium-term.

\section{WORKS CITED}

Accountancy Act. (2015). Updated, SG, issue 95 from 08 December, in effect since 01.01.2016;

Commercial Register. (2020). available at: https://www.brra.bg/

European Commission, (2017) - Guidelines for Preparation and Disclosure of Non-Financial Declaration available online at: https://ec.europa.eu/transparency/regdoc/rep/3/2017/BG/C-2017-4234-F1BG-MAIN-PART-1.PDF

Global Reporting Initiative (2016). - website available at: https://www.globalreporting.org/

Integrated Transport Strategy for the period until 2030 (2017) available online at: https://www.mtitc.government.bg/sites/default/files/integrated_transport_strategy_2030_bg.pdf 
International Integrated Reporting Council - website available at: http://integratedreporting.org/

Kolev O., \& Raynov B., (2017) An Indicative Model for Assessment in the Modification of the Financial and Economic Situation of a Transport Company throughout a Long Period of Time. Mechanics, Transport, Communications Magazine, 15(3/1), article № 1461, III-58-III-63.

Malinovskaya, N., (2016). Integrirovannaya otchetnost': teoriya, metodologiya i praktika. available online at: https://www.old.fa.ru/dep/ods/autorefs/Dissertations/;

National Statistical Institute. (2020). Available at https://www.nsi.bg/

Report of Executive Environment Agency (EEA) in accordance with art.29 of the Regulation on End-of Life Vehicles (EOLV), (2018, November). Available online at http://www.eea.government.bg

Yonkova, B. (2012). Integrated Reporting - Responsibility and Accountability. Izdatelski Kompleks UNWE, Sofia.

Received for publication: $\quad 06.09 .2020$

Revision received: $\quad 23.09 .2020$

Accepted for publication: $\quad 30.12 .2020$

\section{How to cite this article?}

Style - APA Sixth Edition:

Yosifova, D., \& Petrova-Kirova, M. (2021, January 15). Indices of environmental performance of the companies from the automobile sector in the context of integrated reporting. (Z. Cekerevac, Ed.) MEST Journal, 9(1), 207-215. doi:10.12709/mest.09.09.01.24

Style - Chicago Sixteenth Edition:

Yosifova, Desislava, and Magdalena Petrova-Kirova. 2021. "Indices of environmental performance of the companies from the automobile sector in the context of integrated reporting." Edited by Zoran Cekerevac. MEST Journal (MESTE) 9 (1): 207-215. doi:10.12709/mest.09.09.01.24.

Style - GOST Name Sort:

Yosifova Desislava and Petrova-Kirova Magdalena Indices of environmental performance of the companies from the automobile sector in the context of integrated reporting [Journal] // MEST Journal / ed. Cekerevac Zoran. - Belgrade - Toronto : MESTE, January 15, 2021. - 1 : Vol. 9. - pp. 207-215.

Style - Harvard Anglia:

Yosifova, D. \& Petrova-Kirova, M., 2021. Indices of environmental performance of the companies from the automobile sector in the context of integrated reporting. MEST Journal, 15 January, 9(1), pp. 207215.

Style - ISO 690 Numerical Reference:

Indices of environmental performance of the companies from the automobile sector in the context of integrated reporting. Yosifova, Desislava and Petrova-Kirova, Magdalena. [ed.] Zoran Cekerevac. 1, Belgrade - Toronto : MESTE, January 15, 2021, MEST Journal, Vol. 9, pp. 207-215. 